Fecha de recepción: abril 2020

Fecha de aceptación: mayo 2020

Versión final: junio 2020

\section{O Renascimento de Vênus e um novo O Beijo: identidade e representação nas capas da revista Elle Brasil}

Ciro Martins Pires de Oliveira ${ }^{(1)}$, Natália Cabral da Silva Ranhel ${ }^{(2)}$, Simonetta Persichetti ${ }^{(3)}$ e Ana Luiza Coiro Moraes ${ }^{(4)}$

Resumo: $\mathrm{O}$ artigo tematiza a representação de identidades de minorias, por meio de duas capas da edição de dezembro de 2018 da revista Elle, releituras fotográficas do Nascimento de Vênus, de Boticelli e de O Beijo, de Gustav Klimt. Sendo a primeira estampada por uma modelo transexual negra e a segunda um casal de famosos atores negros como protagonistas da releitura. Utiliza-se como instrumento metodológico a análise iconográfica para interpretar os elementos componentes das fotografias. Conclui-se que as imagens trazem novas representações da comunidade negra e transexual, além e ressignificar os quadros através da escolha de seus elementos de destaque ou de anulação.

Palavras chave: Representação - Identidade - Fotografia - Negro - Transexual.

[Resumos em espanhol e inglês na página 72]

(1) Ciro Martins Pires de Oliveira Mestre em Comunicação pela Faculdade Cásper Líbero. Jornalista.E-mail: ciro_martins@outlook.com.

(2) Natália Cabral da Silva Ranhel Mestre em Comunicação pela Faculdade Cásper Líbero. Publicitária. E-mail: na.ranhel@gmail.com.

(3) Simonetta Persichetti, Doutora em Psicologia Social pela Pontifícia Universidade Católica de São Paulo. Professora do Programa de Pós-Graduação em Comunicação da Faculdade Cásper Líbero. spersichetti@casperlibero.edu.br

(3) Ana Luiza Coiro Moraes Doutora em Comunicação Social pela Pontifícia Universidade Católica do Rio Grande do Sul (PUCRS). Professora do Programa de Pós-Graduação em Comunicação da Faculdade Cásper Líbero. alcmoraes@casperlibero.edu.br. 


\section{Introdução}

A proposta deste artigo é uma reflexão acerca de duas capas da Revista Elle de dezembro, que apresentam releituras de pinturas famosas. Em fotografia assinada por Mariana Maltoni, a primeira destas capas traz a modelo transexual Lea T como Vênus de O nascimento de Vênus, de Sandro Botticelli. Já a segunda capa, com fotografia de Gustavo Zylbersztajn, os atores Thaís Araújo e Lázaro Ramos protagonizam O Beijo, de Gustav Klimt. As duas capas fazem parte de uma edição especial de colecionador, em comemoração aos 30 anos da revista no Brasil ${ }^{1}$.

Para tanto, o trabalho efetiva uma interpretação iconológica, segundo Boris Kossoy (2007), fundamentando teoricamente suas análises no conceito de representação trazido por Stuart Hall (2016), André Parente (2011); bem como nos conceitos de identidade e diferença cultural, como articulados por Hall (1996) e Kathryn Woodward (2000).

Assim, buscamos, nestas releituras fotográficas das duas obras de arte, de que forma elas estabelecem interlocução com a representação midiática de identidades de minorias por um pensamento hegemônico. E, principalmente, investigamos o papel midiático em representar estas identidades, podendo expandir o conhecimento quebrando os estereótipos de gênero e de raça ou encolher as identidades a uma pequena gama de opções.

\section{Imagem e representação: construção da realidade}

A cultura clássica grega fez-se referência para boa parte do que foi produzido no Ocidente. Tanto do ponto de vista mitológico quanto filosófico ou artístico, ao pensar nas obras da época percebe-se o quanto prezavam pela harmonia. Eco (2014, p. 72) observa que, para Heráclito, "a harmonia não é ausência, mas o equilíbrio de contrastes" como amor e ódio, paz e guerra, calma e movimento. Levando-se em conta que a filosofia grega abarcava dentro de si a matemática, a química, entre outras ciências, o conceito de harmonia acaba sendo levado também para tais áreas, sendo assim, comparado à simetria. Esta é utilizada em prol da construção de imagens simétricas, buscando alcançar a harmonia, característica principal para se considerar algo belo.

Por mais que os estilos artísticos tenham mudado de diversas formas da Grécia Antiga até a atualidade, uma constante observada é a da representação imagética, cujo intuito é captar o olhar do observador e agradá-lo ou pelo menos prender sua atenção. E, para tanto, cada época, cada cultura, se faz representar por meio dos próprios sistemas de significação, que se amparam na partilha de linguagens, pois "representação refere-se a sistemas simbólicos construídos no interior da linguagem, e [...] por linguagem não se entenda apenas as palavras escritas ou faladas. Queremos dizer qualquer sistema de representação - fotografia, pintura, fala, escrita, imagens feitas através da tecnologia, desenho" (Du Gay et al., 1997, p. 13, tradução nossa).

Nota-se como algumas representações imagéticas criadas na arte da Antiguidade se mantém presentes até hoje, e neste sentido se transformaram, paulatinamente reproduzidas em releituras, em signos. Por exemplo, as figuras mitológicas são constantes nas pinturas, 
ainda que referenciadas por outros símbolos e não por suas representações diretas. Uma imagem que represente a Virgem Maria indiretamente está ligada a imagens anteriores de deusas da fertilidade ou simbolismos ligados ao dom da reprodução dado à mulher. "Um signo é aquilo que se repete. Sem repetição, não há signo, pois não poderíamos reconhecêlo, e é o reconhecimento que origina o signo" (Barthes, 1990, p. 277).

Não por acaso, Stuart Hall (2016) apoia a ligação entre o conceito de representação e as chamadas ciências da linguagem, baseado em três autores e suas teorias: a linguística de Ferdinand de Saussure, a semiologia de Roland Barthes e a teoria do discurso de Michel de Foucault.

Para Saussure (1970), a linguagem é um sistema de sinais. O significante, isto é, a forma, que seria a verdadeira palavra, imagem, foto, associado ao significado, ou seja, a ideia ou conceito na mente das pessoas com a qual a forma é associada, resulta em um signo, que pode ser sons reconhecido em imagens, palavras, pinturas, fotografias, quando elas expressam ou comunicam ideias, e assim se tornam uma unidade significativa.

Já a representação repetida de signos, segundo Barthes (1980), ajuda a criar a cadeia semiológica que sustenta o mito, que se constitui em mensagens de representações cujos suportes são o discurso escrito, mas também a fotografia, o cinema, a reportagem, o esporte, os espetáculos, a publicidade. Em resumo, "toda a unidade ou toda a síntese significativa, quer seja verbal ou visual” (Barthes, 1980, p. 133). Neste sentido,

As matérias-primas da fala mítica (língua propriamente dita, fotografia, pintura, cartaz, rito, objeto, etc.), por mais diferentes que sejam inicialmente, desde o momento em que são captadas pelo mito, reduzem-se a uma pura função significante: o mito vê nelas apenas uma mesma matéria-prima; a sua unidade provém do fato de serem todas reduzidas ao simples estatuto de linguagem. Quer se trate de grafia literal ou de grafia pictural, o mito apenas considera uma totalidade de signos, um signo global, o termo final de uma primeira cadeia semiológica. E é precisamente este termo final que vai transformar-se em primeiro termo ou termo parcial do sistema aumentado que ele constrói (Barthes, 1980, p. 137).

O aporte foucaultiano como referência de Hall (2016) na construção do conceito de representação se dá porque Foucault trata da produção do conhecimento e do sentido a partir da formação discursiva a qual um texto ou uma prática pertence. Contudo, essa produção é sempre atravessada por questões de poder e do corpo, e isso expande enormemente o escopo do que está envolvido no conceito de representação. A célebre descrição de Foucault (1995) ao quadro Las Meniñas, de Velázquez (Figura 1), é emblemática para a compreensão do conceito, sobretudo quando propõe uma análise que parte do olhar do pintor (o próprio Velázquez) retratado na obra. É este olhar e sobretudo para onde ele se dirige (para fora do quadro) que posiciona os sujeitos, pois para que se veja, por exemplo, a imagem do casal real refletida no espelho, é preciso seguir a sugestão da representação. Dessa forma, o espelho é analisado como sendo a representação da representação, já que seu reflexo é a reprodução do que está fora do quadro como presença física. 


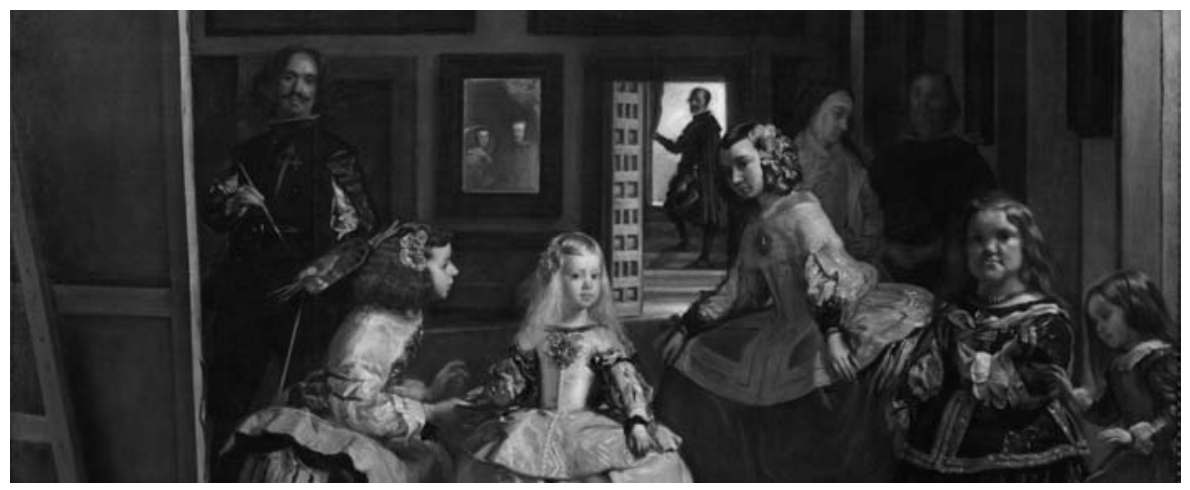

Figura 1. Las Meniñas, de Diego Velázquez. Fonte: http://www.donquijote.co.uk/blog/las-meninas

Talvez haja, neste quadro de Velásquez, como que a representação da representação clássica e a definição do espaço que ela abre. Com efeito, ela intenta representar-se a si mesma em todos os seus elementos, com suas imagens, os olhares aos quais ela se oferece, os rostos que torna visíveis, os gestos que a fazem nascer. Mas aí, nessa dispersão que ela reúne e exibe em conjunto, por todas as partes um vazio essencial é imperiosamente indicado: o desaparecimento necessário daquilo que a funda daquele a quem ela se assemelha e daquele a cujos olhos ela não passa de semelhança. Esse sujeito mesmo -que é o mesmo- foi elidido. E livre, enfim, dessa relação que a acorrentava, a representação pode se dar como pura representação (Foucault, 1995, p. 21).

Sintetizando, é possível dizer que os sentidos são construídos através dos discursos, tanto textuais como imagéticos, produzindo a representação, que norteia a forma como cada um entende e assimila a informação que é dada. Isso porque, pensando em como são apropriados socialmente os sistemas simbólicos, o termo representação pode designar "o uso dos variados sistemas significantes disponíveis (textos, imagens, sons) para 'falar por' ou 'falar sobre' categorias ou grupos sociais, no campo de batalha simbólico das artes e das indústrias da cultura" (Freire, 2005, p. 18).

Em outra parte, ainda, nós concedemos sentidos às coisas pela maneira como as representamos - as palavras que usamos para nos referir a elas, as histórias que narramos a seu respeito, as imagens que delas criamos, as emoções que associamos a elas, as maneiras como classificamos e conceituamos, enfim, os valores nelas embutidos (Hall, 2016, p. 21). 
Assim, as narrativas jogam luz nas questões sobre a identidade e seus desafios, como o de combater a normatividade de comportamentos heterossexuais, brancos e cisgêneros. Hall (2016) ressalta a importância da linguagem no âmbito de significação e identificação das partes, "para significar ou representar para outros indivíduos nossos conceitos, ideias e sentimentos" (p. 18).

A questão central, aqui, é a relação da identidade com a representação. Para Du Gay et al. (1997), o conceito de identidade trata do posicionamento dos sujeitos no interior das representações, e está relacionado aos processos de subjetivação do indivíduo e de sua caminhada na direção do tornar-se sujeito. Woodward (2000) complementa que "é por meio dos significados produzidos pelas representações que damos sentido à nossa experiência $\mathrm{e}$ àquilo que somos" (Woodward, 2000, p.18). A autora ainda sugere que é com esta relação dos sistemas simbólicos que se torna possível dizer aquilo que se é e aquilo que se pode tornar-se, isto é, está dentro dos discursos e sistemas de representação a construção do posicionamento e os lugares de fala dos sujeitos.

\section{Identidade, diferença e os sujeitos da cultura}

Assunto central nos Estudos Culturais, a identidade cultural vem fundamentando pesquisas que envolvem questões de gênero, de classe, de raça e etnia, e de confrontos como modernidade x pós-modernidade, local x global, etc. Tais estudos, em sua maioria, se valem do que postulou Hall em A identidade cultural na pós-modernidade, onde ele considera as mudanças no conceito de identidade de duas maneiras: $1^{\text {a }}$ ) apresentando três concepções de identidade dos sujeitos através dos tempos (o sujeito do Iluminismo, o sujeito sociológico e o sujeito pós-moderno) e justificando que as desenvolveu porque o prefixo pós não se aplica apenas à noção de modernidade, aplica-se, também, a "qualquer concepção essencialista ou fixa de identidade"; $2^{a}$ ) refletindo sobre a mudança nas identidades culturais, isto é, os aspectos que surgem do pertencimento dos sujeitos a "culturas étnicas, raciais, linguísticas, religiosas e, acima de tudo, nacionais” (Hall, 2005, pp. 8-10).

$\mathrm{O}$ autor defende que o processo identitário tem muito a ver com o que os sujeitos podem se tornar, como eles têm sido representados e como essa figuração organiza o modo como eles podem se auto-representar. Segundo Hall (2000, p. 108-109), “elas [as identidades] não são nunca singulares, mas multiplamente construídas ao longo de discursos, práticas e posições que podem se cruzar ou ser antagônicas". Para ele, a identidade não pode ser tomada como essência fixa ou como um processo findável, que tenha um ponto final. Ao contrário,

Deveríamos pensá-la, talvez como uma "produção" que nunca se completa, que está sempre em processo e é sempre constituída interna e não externamente à representação. Esta visão problematiza a própria autoridade e autenticidade que a expressão "identidade cultural" reivindica como suas (Hall, 1996, p. 68).

Rutherford (1990) defende que a identidade é o ponto de encontro do passado dos sujeitos com suas relações sociais, culturais e econômicas de sua atualidade, sendo uma "inter- 
secção de nossas vidas cotidianas com as relações econômicas e políticas de subordinação e dominação" (pp. 19-20). Bauman (2001) acentua que há um desejo em solidificar o processo de identificação e que socialmente é construída uma falsa harmonia e consciência deste processo de identificação. "A busca da identidade é a busca incessante de deter ou tornar mais lento o fluxo, de solidificar o fluido, de dar forma ao disforme" (Bauman, 2001, p. 99). Porém, o autor argumenta que este é um processo equivocado e sem fim.

Mas as identidades, que não tornam o fluxo mais lento e muito menos o detêm, são mais parecidas com crostas que vez por outra endurecem sobre a lava vulcânica e que se fundem e dissolvem novamente antes de ter tempo de esfriar e fixar-se (Bauman, 2001, p. 99)

Por outro lado, para Kathryn Woodward (2000) as identidades são ainda engendradas pela marcação da diferença, que "ocorre tanto por meio de sistemas simbólicos de representação quanto por meio de formas de exclusão social. A identidade, pois, não é o oposto da diferença: a identidade depende da diferença” (Woodward, 2000, pp. 39-40).

A autora defende que, por exemplo, o "ser negro" e o "ser mulher" só existem conceitualmente porque há uma marcação de diferenças, ou seja, há distinção entre o ser mulher e o ser homem, ser negra e ser branca, ser cisgênero e ser transexual. A identidade, de certa forma, só existe se houver a diferença.

A política de identidade concentra-se em afirmar a identidade cultural das pessoas que pertencem a um determinado grupo oprimido ou marginalizado. Essa identidade torna-se, assim, um fator importante de mobilização política. Essa política envolve a celebração da singularidade cultural de um determinado grupo, bem como a análise de sua opressão específica. Pode-se apelar à identidade, entretanto, de duas formas bastante diferentes (Woodward, 2000, p. 35).

As duas formas às quais se refere Woodward (2000) são: as essencialistas e a dos novos movimentos sociais, esta última indo ao encontro da proposta do presente texto. As essencialistas seriam, como diz o próprio nome, grupos que procuram as essências que julgam fixas e que os separam de um outro grupo sem a mesma característica, por exemplo, "tomando como base a identidade e as qualidades singulares das mulheres, alguns grupos feministas têm argumentado em favor de um separatismo relativamente aos homens" (Woodward, 2000, p.35). Mas há, por outro lado, novos movimentos sociais que adotam a identidade como algo mutável.

Eles têm enfatizado que as identidades são fluidas, que elas não são essências fixas, que elas não estão presas a diferenças que seriam permanentes e valeriam para todas as épocas (Weeks, 1994). Alguns membros dos "novos movimentos sociais" têm reivindicado o direito de construir e assumir a responsabilidade de suas próprias identidades. Por exemplo, as mulheres negras têm lutado pelo reconhecimento de sua própria pauta de luta no interior do movimento feminista, resistindo, assim, aos pressupostos de um movimento de mulheres 
baseado na categoria unificada de "mulher" que, implicitamente, inclui apenas as mulheres brancas (Woodward, 2000, p. 36).

Desta forma, a identidade surge no interior da representação da diferença.

Nas relações sociais, essas formas de diferença - a simbólica e a social - são estabelecidas, ao menos em parte, por meio de sistemas classificatórios. Um sistema classificatório aplica um princípio de diferença a uma população de uma forma tal que seja capaz de dividi-la (e a todas as suas características) em ao menos dois grupos opostos - nós/eles (por exemplo, sérvios e croatas); eu/ outro (Woodward, 2000, p. 40).

A relação binária que se estabelece entre o "Eu” e o "Outro" é que irá sublinhar a diferença entre as identidades. Diferença que pode ser construída culturalmente, como é o caso da temática deste artigo, no qual as identidades de mulher transexual (a capa da Elle com a modelo transexual como Vênus) e de negros (os atores Thaís Araújo e Lázaro Ramos na releitura de $O$ Beijo) são discutidas. Logo, é importante frisar, referendados no pensamento de Woodward (2000), que estas diferenças existem e de que forma a revista Elle contribui para a representação das identidades transexual e negra em sua edição especial.

A diferença pode ser construída negativamente - por meio da exclusão ou da marginalização daquelas pessoas que são definidas como "outros" ou forasteiros. Por outro lado, ela pode ser celebrada como fonte de diversidade, heterogeneidade e hibridismo, sendo vista como enriquecedora: é o caso dos movimentos sociais que buscam resgatar as identidades sexuais dos constrangimentos da norma e celebrar a diferença (Woodward, 2000, pp. 50-51).

\section{A fotografia como sistema de representação}

Ao seu surgimento, a fotografia foi tida como aquela que substituiria outras formas de arte na condição de reprodutora da realidade, fica claro que ainda assim continua a beber das mesmas fontes para sua criação. $\mathrm{O}$ espectador a vê como verdade enquanto o fotógrafo a cria sempre referenciando outros tipos de imagens para melhor assimilação por parte de quem vê.

A relação verdade/mentira na imagem fotográfica é sempre ambígua e complexa. A fotografia é uma forma de registro, não um aparelho detector de verdades e mentiras. A matéria-prima da imagem fotográfica é a aparência (...) o objeto da representação. A fotografia se refere, portanto, à realidade externa dos fatos, das fantasias e das coisas do mundo e nos mostra uma determinada visão iconográfica do objeto representado, uma outra realidade: a realidade fotográfica, isto é, uma segunda realidade (Kossoy, 2007, p. 155). 
Para ter a construção desta segunda realidade se torna necessário o uso de consensos coletivos, representações que trabalhem elementos passíveis de leitura por aqueles que a verão. Isto envolve o ambiente cultural onde a imagem será consumida em relação ao ambiente de sua produção. A cultura requer ser avaliada em função de sua recepção, das apropriações e dos desvios que ela ocasiona (Caune, 2008).

A representação da mensagem, então, fica por conta dos signos reproduzidos na fotografia - que são de conhecimento de ambas as partes. A imagem não só retrata a realidade, mas conta algo sobre um dado momento da cultura e da sociedade, dependendo do seu simbolismo.

Reafirmo que as novas imagens são um sintoma, entre muitos, de um determinado estado de cultura em que a prevalência da imagem, resultado de sua importância cognitiva, em especial na arte e na ciência, revela uma tradição problemática marcante em nossa civilização desde o Renascimento. Não é o mundo real, mas a maneira de inventar o mundo possível que aqui interessa, e não apenas uma perspectiva estética, mas também ética e política (Parente, 2011, p. 54).

Ao fazer releituras de pinturas ou outros tipos de arte na cultura contemporânea utilizando de informações e simbolismos atuais, como em ambas as fotografias analisadas neste artigo, reinventa-se a significância de tal imagem, utilizando do contexto atual e de conceitos éticos e políticos contemporâneos para ler esta nova imagem tendo como pano de fundo os conceitos e contextos da imagem original.

Ainda assim, esta imagem, mesmo que recolocada em um contexto atual, somente será reconhecida efetivamente se o espectador já a conhece. Isso se dá por meio da construção da imagem utilizando-se da memória coletiva para alimentar estereótipos que farão com que a pessoa consiga ler a fotografia por meio de valores já normatizados.

Entende-se então que, toda análise da imagem, feita aqui ou em qualquer outro lugar tem por base os parâmetros culturais, de memória e a temporalidade social daquele que a examina.

\section{Análise iconográfica das capas da Elle}

Metodologicamente operamos os conceitos de identidade e representação junto à análise iconográfica da imagem, de Boris Kossoy (2001), para quem a análise iconográfica tem a intenção de dar atenção aos detalhes das imagens e seus elementos formativos, tanto no aspecto literal quanto no descritivo, destacando o tempo e espaço em que ambos estão circunscritos para que a identificação seja possível.

A análise iconográfica, no caso da representação fotográfica, situa-se a meio caminho da busca e do significado do conteúdo; ver; descrever e constatar não é o suficiente. É este o momento de uma incursão em profundidade na cena 
representada, que só será possível se o fragmento visual for compreendido em sua interioridade. Para tanto, é necessária, a par de conhecimentos sólidos acerca do momento histórico retratado, uma reflexão centrada no conteúdo, porém, num plano além daquele que é dado ver apenas pelo verismo iconográfico (Kossoy, 2001, p. 110).

Desta maneira, ainda segundo o autor, para que haja compreensão mais elaborada sobre a fotografia em questão, as partes analisadoras devem recorrer ao contexto histórico e cultural em que a imagem se insere. Kossoy (2001) ainda salienta que o registro ou testemunho fotográfico possui um significado relativo, isto é, não é domado pela suposta verdade e nem se comporta como cópia fidedigna de uma realidade. "Sua materialização sempre se fez a partir do fotográfico, um processo, pois marcado pela subjetividade" (Kossoy, 2001, p. 118).

\section{Análise iconográfica de $O$ Nascimento de Vênus}

No caso da capa da Elle estampada pela modelo transexual e negra, Lea T, como a Vênus de Boccitelli (Figura 2), a fotografia é a releitura da obra de Sandro Botticelli O nascimento de Vênus, pintada por volta de 1486 .

Para Garcia, com sua Vênus, "Botticelli quis antes perpetuar o tipo esbelto das moças florentinas de seu tempo, com a pele marfim, gestos suaves, cabelos dourados e ondulados e o perfil oval do rosto" (Garcia, 2005/2006, p. 119).

Vênus é bela e pudica, por isso representa a verdade cristã, uma vez que, segundo Ficino, para alçá-la as únicas vias possíveis eram o amor e a beleza. Vênus é amor e beleza. A arte, dessa forma, assume-se como religião, uma vez que revela ou pelo menos conduz seus espectadores a esta revelação. Está no domínio do visível, portanto, no domínio da realidade; daí Vênus representar a verdade divina, idealizada, embelezada e atraente [...] É de fato a figura divina venusiana que expressa esse valor supremo, uma vez que sua anatomia é monumental, expressa a suprema e complexa beleza, mesmo desnuda (Garcia, 2005/2006, p. 120).

A partir da contribuição da autora, esta pesquisa interpreta que o significado da obra é legatário de uma cadeia semiológica (Barthes, 1980), que volta ao mito da deusa romana Vênus, onde se origina a síntese significativa que chega a Botticelli como símbolo da beleza e pureza das moças cristãs de Florença. Trata-se das possibilidades múltiplas e plurais de interpretação das imagens fotográficas, a que se refere Kossoy (2002).

As imagens fotográficas, por sua natureza polissêmica, permitem sempre uma leitura plural, dependendo de quem as aprecia. Os receptores já trazem em si suas próprias imagens mentais preconcebidas acerca de determinados assuntos. Estas imagens mentais funcionam como filtros ideológicos culturais, morais, éticos, etc (Kossoy, 2002, p.45). 


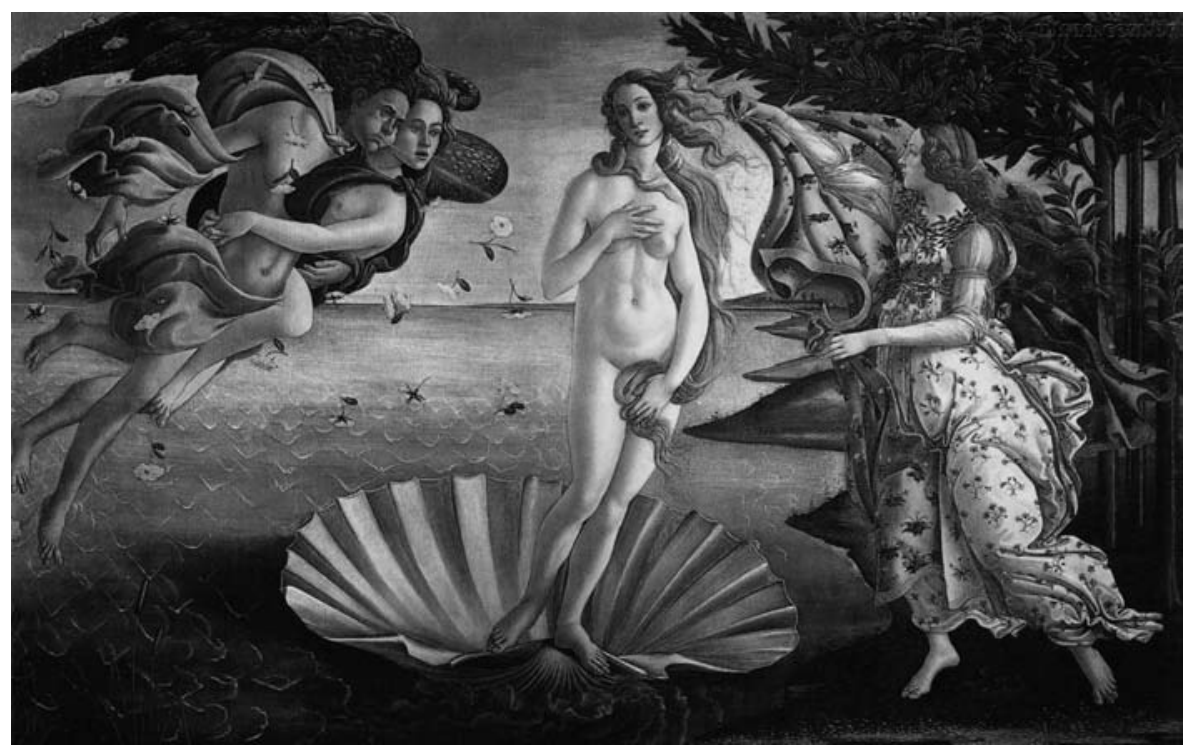

2

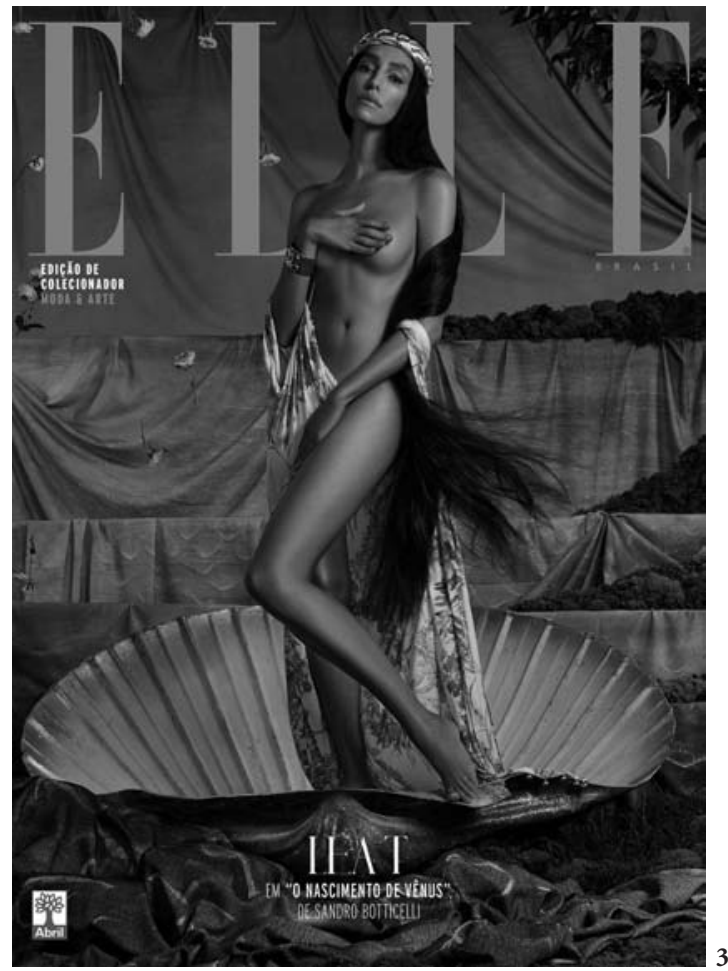

Figura 2. O nascimento de Vênus. Figura 3. Lea T na capa da revista Elle. Fonte: Capa da Elle de dezembro de 2018. Foto de Mariana Maltoni. 
Já quando Mariana Maltoni escolhe O nascimento de Vênus como cenário de discussão, a fotógrafa confere uma nova identidade para o trabalho (Figura 3). Ao escolher a modelo transexual e negra (aspectos importantes para esta discussão) para estar no lugar na protagonista da pintura de Botticelli, Maltoni cria uma nova representação imagética, que leva à discussão sobre o conceito de beleza feminina e expande a identidade cultural do que é ser mulher, mais precisamente no Brasil. Em entrevista, a modelo Lea T diz que "a própria Vênus, que refizemos para esta capa, é um símbolo de nudez pura, e não pervertida”"2.

Estudei artes em Florença, por isso pensei muito no significado desse quadro e cheguei à conclusão de que ela é a mulher perfeita. Então, falei para mim mesma: 'Por que não?' Por que não posso ser a Vênus de Boticelli? Eu posso ser perfeita mesmo tendo as minhas imperfeições. No fim das contas, todas as mulheres podem representar essa figura (Lea T, 2018, s/p).

Retomando o conceito de identidade e diferença articulado por Woodward (2000), a partir do momento em que esta diferença (no caso transexual negra) é posta na capa de uma revista e representada na forma de símbolo de feminilidade, ela é celebrada e não mais marginalizada ou estereotipada. A releitura, assim, se torna a representação da representação clássica, na acepção foucaultiana, apresentando novas possibilidade para a identidade cultural transexual e negra através da fotografia.

Quando Kossoy (2002, p. 57) argumenta que a interpretação iconológica busca "decifrar a realidade interior da representação fotográfica, sua face oculta, seu significado, sua primeira realidade, além da verdade", ele reafirma que há possibilidades de interpretação que avançam e atropelam o olhar da superfície, sendo indispensável a discussão sobre aquilo que está nas sombras da imagem, no que não diz.

Ao reler a obra de Botticelli com uma modelo transexual negra representando Vênus, a revista vai além do seu aspecto estético, aprofundando o caráter social e cultural da comunicação, e desta forma trazendo novas possibilidades de representação de identidades para além das heteronormativas, usualmente presentes na imprensa. Além disto, a imagem da revista se desprende de todos os outros elementos que estão presentes na pintura de Botticelli e joga o foco de luz somente na questão da imagem da mulher, no caso representada por Lea T. Desta forma, a fotógrafa fez uma releitura e recria o ambiente da pintura de forma que a discussão acerca da sensualidade feminina representada por uma mulher transexual se torna o epicentro do seu discurso imagético. Esta importância é reforçada pelo cenário social em que esta re-apresentação é dada, pois do dia $1^{\circ}$ de outubro de 2015 a 30 de setembro de 2016 foram 123 mortes no Brasil, que assim se tornava o país que mais mata pessoas transexuais no mundo ${ }^{3}$.

A Rede Trans Brasil disponibilizou nesta segunda-feira (30) um dossiê traçando um raio-x das travestis, transexuais e transgêneros no país. Batizado de "A Geografia dos Corpos das Pessoas Trans", o relatório traz informações muito importantes sobre a transfobia e os alto índices de violência. De acordo com pesquisa do IBGE (Instituto Brasileiro de Geografia e Estatística) de 2013, a 
expectativa de vida desse grupo social não passa dos 35 anos, menos da metade da média nacional de 74,9 anos da população em geral ${ }^{4}$.

\section{Análise iconográfica das capas da Elle: $O$ Beijo}

O Beijo, de Gustav Klimt (Figura 4), é um dos primeiros expoentes da Art Nouveau 5 . A obra foi exposta pela primeira vez em 1908 e seu criador, morador de Viena, viveu na época em que a cidade era o centro dos estudos da sexualidade. Por conta disso, as interpretações e críticas relacionadas à obra, de forma geral, tendem à sua leitura com conotação sexual. Nadja Pinheiro, psicanalista e doutora em Psicologia Clínica atenta, ainda, ao apelo para a mitologia grega que traz a pintura de Kint. Trata-se do signo que ao se repetir forma uma cadeia semiológica (Barthes, 1990), que se completará na fotografia que faz a releitura da primeira representação imagética.

Klimt recorre aqui (tal como Freud) à mitologia grega para expressar o que deseja. Danae era filha do rei de Argos que a trancou em uma torre onde nenhum homem poderia dela desfrutar. Porém, Zeus, deus dos deuses, se transforma em chuva de ouro para poder fazer de Danae uma mulher. [Zeus] se faz presente através da erotização fantasiada que a ela chega sem compreensão e conhecimento racionais, através de um Outro que se mostra grandioso em seu fazer, em sua ação de afetização, como ouro, como deus, como pó, como chuva de afeto desconhecida (Pinheiro, 2008, s/p).

Ao interpretar a obra de Klint sob o ponto de vista psicanalítico, Pinheiro (2008) ressalta novamente a influência de Freud, tanto em relação ao dualismo, que contrasta, e de certa forma contrapõe, o papel ativo masculino e o passivo feminino. Aponta, também, a ilusão e a eterna possibilidade de finitude da paixão.

Em nenhuma outra tela o dualismo (tão caro ao pensamento freudiano) se apresenta de forma tão intensa e explícita quanto nessa: nas linhas retas do manto masculino em contraposição às flores e traços arredondados do manto feminino; no contraste entre a pele clara da mulher e a pele escura do homem; entre a atividade presente no ato de abraçar masculino em oposição à passividade da entrega feminina (não esqueçamos que Freud fez equivaler atividade- masculinidade e passividade-feminilidade). Para além do dualismo, a tela tematiza também outra importante questão psicanalítica: a relação amorosa. Se à primeira vista, a tela parece apontar para a possibilidade de ocorrência de um encontro perfeito entre duas pessoas, ilusão que se estabelece no momento da entrega apaixonada, o detalhe destacado por Klimt, que a um passo da entrega, efetivada sobre um convidativo e inocente campo florido, abre-se um abismo sem fim, demonstra que basta um pequeno deslize, um simples desencaixe que o impossível da relação afetiva se faz, nos precipitando ao vazio (Pinheiro,2008, s/p). 


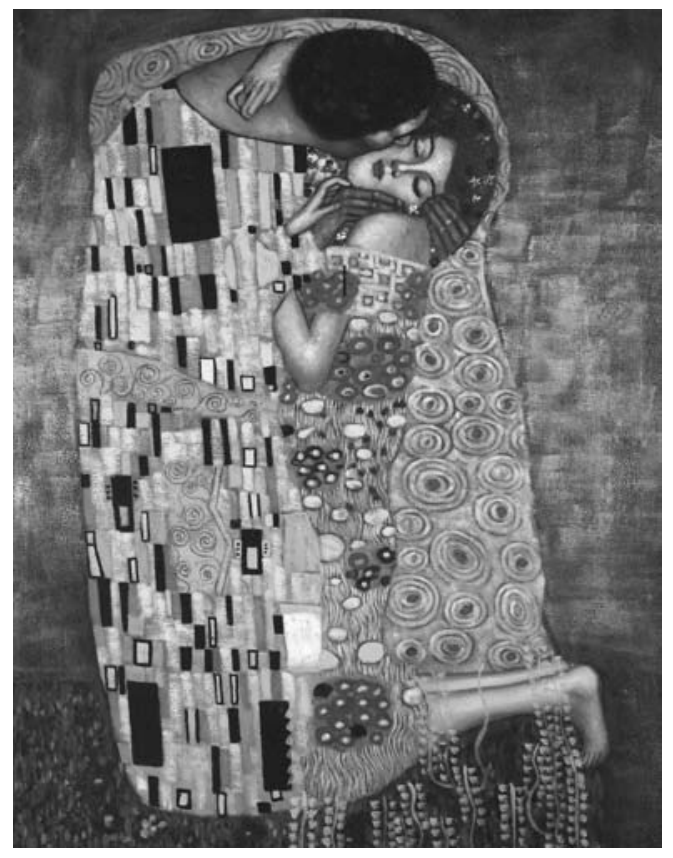

4

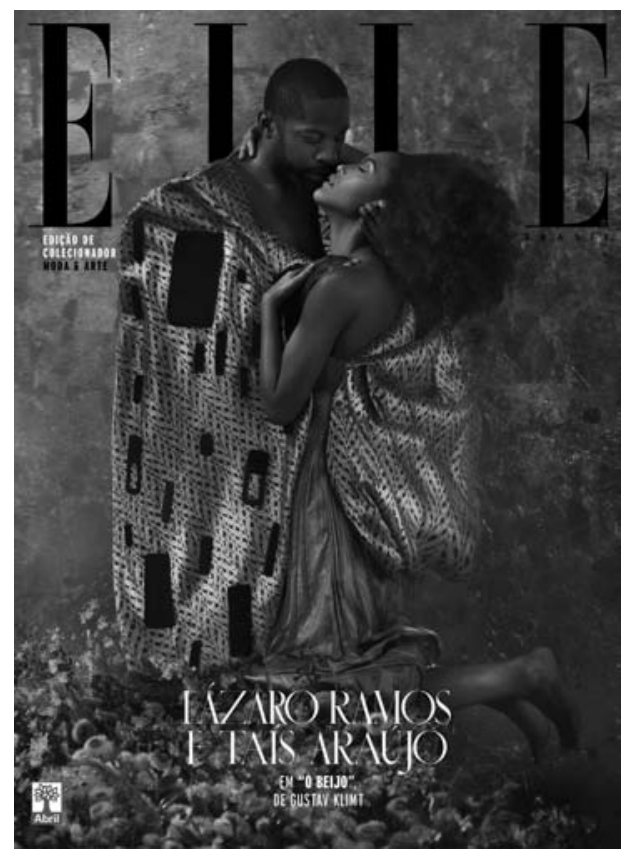

5

Figura 4. O Beijo de Gustav Klimt. Fonte: Quadro de Gustav Klimt, O Beijo. Figura 5. Lázaro Ramos e Thaís Araújo em O Beijo. Fonte: Capa da Elle de dezembro de 2018. Foto de Gustavo Zylbersztajn.

Na releitura da obra na capa da revista Elle (Figura 5), ainda que se repitam os mesmos elementos estéticos, como as estampas, a cor predominantemente dourada e as flores, não se verifica a mesma atitude entre o casal, sobretudo no que diz respeito à identidade feminina na imagem. Thais Araújo não está com a face voltada para fora do ato erótico, como a mulher representada em $O$ Beijo de Klint, ela também é parte ativa. Se, na obra de Klimt, é representado um homem tomando uma mulher, na capa da Elle o que é visto é um casal em atitude erótica, mas também amorosa, homem e mulher referenciados como exemplo de relação afetiva feliz e duradoura no meio artístico brasileiro.

A representação imagética que o ocupa esta capa da Elle reforça o lugar de destaque que Lázaro Ramos e Taís Araújo vem ganhando na mídia, não apenas como casal referência de relacionamento, mas como atores e militantes da causa negra, de forma a enaltecer o amor entre os dois ao colocá-los ocupando tal posição dentro da releitura de O Beijo.

Contudo, o que traz maior destaque para a questão da identidade nesta releitura é exatamente a diferença maior entre a obra original e a retratada: a troca do casal branco pelo 
negro. O olhar do espectador é atraído pelo que há de diferente, se não seria apenas uma releitura idêntica a obra original, ao incluir na releitura um casal negro são aportadas novas significações para a imagem. A fotografia, na releitura do quadro de Klint, apropria-se dos signos nesta presentes para construir socialmente uma nova ordem de sistema simbólico, cuja representação aponta para identidades que se posicionam culturalmente sob outro registro: libertário e amoroso.

Isso porque, ao colocar figuras públicas no lugar do casal retratado, inclui-se também na interpretação as pautas levantadas e defendidas por eles. A pintura, que até então, para o autor era uma crítica aos costumes sexuais de sua época, e recebia uma leitura do público em geral de se tratar de uma imagem envolta em sensibilidade, nesta releitura fotográfica ressalta o empoderamento e o poder cultural do povo negro.

\section{Considerações finais}

Ambas as pinturas escolhidas como cenário para as fotografias são sígnicas, possuem os seus primeiros significados e imbricações. Ao fazer uma releitura, excluindo elementos, fixando algumas partes e, principalmente, escolhendo os seus protagonistas, a revista Elle estabelece uma representação discursiva que vai além do que se vê nas imagens. Quando a Vênus de Botticelli é retratada por uma modelo transexual negra e os protagonistas de O Beijo de Klimt são dois atores negros, o discurso torna-se muito mais político, tendo em vista as violências que estas comunidades sofrem, tanto o racismo como a transfobia. O renascimento de Vênus vem com esta discussão da identidade feminina e como esta identidade é mutável e seus símbolos de beleza podem possuir outras representações além das veiculadas exaustivamente pela imprensa. Estas identidades nascem e renascem constantemente no ambiente social e, por isso, também é importante que este ciclo de representação seja retratado e re-apresentado na grande imprensa, através de discursos textuais e imagéticos (como é o caso deste artigo). Com Um novo beijo estabelece um paralelo com a pintura de Klimt e a conjuntura social atual do país, por isso é importante analisar os elementos originais da obra e os que foram traçados para sua releitura. No caso desta capa, há uma ressignificação dos elementos originais maiores do que na capa estampada por Lea T. Nela os componentes originais são repensados e re-apresentados de forma que o afeto e celebração da cultura negra são os pontos norteadores da fotografia.

Com isto, é possível concluir que a imagem é uma grande aliada da transformação cultural, pois possui no clique a possibilidade de criar e recriar representações de identidades culturais que estão dentro da diferença. Esta diferença pode ser construída através de variados contextos (histórico, social, cultural, econômico, político), mas deve ser sempre celebrada e não anulada ou reduzida a representações fixas. 


\section{Notas}

1. As duas capas fazem parte de uma edição especial de colecionador em comemoração dos 30 anos da revista no Brasil e conta com mais três versões de capas: com Sônia Braga como Mona Lisa (de Leonardo Da Vinci), José Celso Martinez Corrêa em O Grito (de Munch) e Caetano Veloso como Joiners (de David Hockney).

2. Disponível em: https://elle.abril.com.br/moda/lea-t-todas-as-mulheres-podem-repre sentar-a-venus-de-boticelli/. Aceso em: 12 jun. 2018.

3. Disponível em: https://noticias.r7.com/brasil/brasil-lidera-assassinatos-de-pessoastrans-no-mundo-30012017. Acesso em: 13 jun. 2018.

4. Disponível em: https://noticias.r7.com/brasil/brasil-lidera-assassinatos-de-pessoastrans-no-mundo-30012017. Acesso em: 13 jun. 2018.

5. Movimento artístico surgido no final do século XIX, que se manteve em voga nas duas primeiras décadas do século XX.

\section{Referências}

Barthes, R. (1990). O óbvio e o obtuso. Rio de Janeiro: Nova Fronteira.

. (1980). Mitologias. São Paulo: Difel.

Bauman, Z. (2012) Ensaios sobre o conceito de cultura. Rio de Janeiro: Jorge Zahar.

Caune, J. (2008). As relações entre cultura e comunicação: núcleo epistêmico e forma simbólica. Líbero. Ano XI - no 22 - Dez. Disponível em http://seer.casperlibero.edu.br/index.php/ libero/article/view/556/528. Acesso em 11 jun.2019.

Camargo, P. y Monteiro, G. L. T. (2018). “Todas as mulheres podem representar a Vênus de Boticelli”. Disponível em: http://www.justicadesaia.com.br/lea-t-todas-as-mulherespodem-representar-a-venus-de-boticelli/. Acesso em: 12 jun. 2019.

Eco, U. (2014). História da beleza. Rio de Janeiro: Record.

Foucault, M. (1995). As palavras e as coisas: uma arqueologia das ciências humanas. $7^{\mathrm{a} e d .}$ São Paulo: Martins Fontes.

Freire Filho, J. (2005). "Força de expressão: construção, consumo e contestação das representações midiáticas das minorias". Revista FAMEcoS. Porto Alegre: no 28, dez.

Garcia, F. (2005/2006). "Uma leitura hegeliana narrativizada de O nascimento de Vênus, de Sandro Botticell”. Revista Educação, Arte e História da Cultura. Volume 5/6. Número 5/6. São Paulo.

Hall, S. (2016). Cultura e representação. Rio de Janeiro: Ed.PUC-Rio/Apicuri. . (1996). "Identidade cultural e diáspora". Revista do Patrimônio Histórico e Artístico Nacional, n.24, Pp. 68-75. . (2005). A identidade cultural na pós-modernidade. Rio de Janeiro: DP\&A. . (2000). “Quem precisa de identidade?". In: Silva, Tomaz T. (Org). Identidade e Diferença. São Paulo: Vozes.

Kossoy, B. (2001). Fotografia \& História. São Paulo: Ateliê Editorial. . (2002). Realidades e ficções na trama fotográfica. São Paulo: Ateliê Editorial. 
. (2007). Os tempos da fotografia: o efêmero e o perpétuo. Cotia: Ateliê Editorial. Parente, A. (2011). “Novas imagens: efeitos e modelos”. In Parente, A.; COUCHOT, E. (Org.). Imagem-máquina: a era das tecnologias do virtual. Rio de Janeiro: Editora 34.

Pinheiro, N. N. B. (2008). Freud e Klint em Viena "fin-de-siècle": interfaces entre psicanálise e arte. Cógito, 9, 42-45. Disponível em http://pepsic.bvsalud.org/scielo.php?script=sci_ arttext\&pid=S1519-94792008000100008\&lng=pt\&tlng=pt. Acesso em 13 ago.2019.

Santos, B. S. (1988). "Um discurso sobre as ciências na transição para uma ciência pósmoderna”. Revista Estudos Avançados. Vol.2 no.2 São Paulo Mai/Ago. Disponível em: http://www.scielo.br/scielo.php?pid=s0103-40141988000200007\&amp;script=sci_art text. Acesso em 10 ago.2019.

Saussure, F. (1970). Curso de Linguística Geral. Charles Bally; Albert Sechehaye (org.). Antônio Chelini, José Paulo Paes e Izidoro Blikstein (Trad.) 3a ed. São Paulo: Cultrix.

Woodward, K. (2000). “Identidade e diferença: uma introdução teórica e conceitual”. In Silva, T. T. da. (org.) Identidade e diferença: a perspectiva dos estudos culturais. Petrópolis: Vozes.

Resumen: El artículo analiza la representación de identidades minoritarias a través de dos portadas de la edición de diciembre de 2018 de la revista Elle, relecturas fotográficas del "Nacimiento de Venus", Boticelli y "El Beso" de Gustav Klimt. Siendo la primera de una modelo transexual negra y la segunda una pareja de famosos actores negros brasileños como protagonistas de la relectura. Se utiliza como instrumento metodológico el análisis iconográfico para interpretar los elementos componentes de las fotografías. Se concluye que las imágenes traen nuevas representaciones de la comunidad negra y transexual, además de resignificar las imágenes al elegir sus elementos de prominencia o anulación.

Palabras clave: Representación - Identidad - Fotografía - Negro - Transexual.

Abstract: The article focuses on the representation of minority identities, through two covers of the December 2018 edition of Elle magazine, photographic readings of the Birth of Venus, by Boticelli and O Beijo, by Gustav Klimt. The first being printed by a black transsexual model and the second a couple of famous black actors as protagonists of the reinterpretation. Iconographic analysis is used as a methodological tool to interpret the component elements of the photographs. It is concluded that the images bring new representations of the black and transsexual community, in addition to giving new meanings to the pictures through the choice of their prominent or nullifying elements.

Keywords: Representation - Identity - Photography - Black - Transsexual.

[Las traducciones de los abstracts fueron supervisadas por el autor de cada artículo] 